\title{
Mammalian host defense peptides and their implication on combating
}

Leishmania infection

Zahra Abdossamadi, Negar Seyed, Sima Rafati* 


\section{Abstract}

33 Infection with parasites of the genus Leishmania is a health problem in many countries around

34 the world. No effective vaccine is available against leishmaniasis, so chemotherapy is the only 35 alternative for treatment of all forms of the disease. However, drawbacks including toxicity and 36 severe adverse reactions restrain the use of currently available chemotherapeutics. Therefore 37 development of new drugs and therapeutic approaches is highly demanded. Mammalian host 38 defense peptides (mHDP) and/or mammalian antimicrobial peptides (mAMP) are among 39 promising compounds considered effective to control the infectious diseases. These are potential 40 multifunctional molecules that modulate the immune response besides direct killing of 41 pathogens. Here we have reviewed the hallmark characteristics of the mHDPs in respect to the 42 potential role they can play against leishmaniasis.

43 Keywords: Leishmania; Mammalian host defense peptides; Mammalian antimicrobial peptides; 44 Therapy.

45 46 47 48 49 50 51 52 53 54 55 
Infection with Leishmania protozoan parasites is associated with remarkable morbidity and mortality worldwide. World Health Organization has reported that leishmaniasis is still one of the most important neglected diseases primarily affecting poor regions in Africa, Asia, central and South America and Mediterranean basin [1]. Twenty one different pathogenic Leishmania species have been so far identified [2]. Based on the phenotype, leishmaniasis is categorized in three main forms: visceral leishmaniasis (VL), cutaneous leishmaniasis (CL) and mucocutaneous leishmaniasis [3]. Increased incidence of leishmaniasis in HIV-infected individuals is now a major concern [4].

Leishmania has a digenetic life cycle consisting of extracellular flagellated promastigotes and intracellular aflagellated amastigotes. After transmission from the sand fly vector to the host, Leishmania promastigotes differentiate into amastigotes in the lysosomes (due to the acidic $\mathrm{pH}$ ) and trigger the onset of disease symptoms [5,6]. Therefore, parasite eradication is a big deal because of its complex digenetic life cycle with different metabolisms, protein expression and membrane composition. Additionally the disease is almost restricted to poverty-stricken regions, which further complicates the problem resolution [7]. Unfortunately, no protective vaccine is available yet, which leaves the disease control still on chemotherapy. However increased rate of antibiotic resistance especially against antimonials as first line drug, side effects as toxicity of some drugs and limitations of expensive second line drugs as miltefosin and fluconazole for under-developed and developing countries, urges new drugs to be developed [8-10]. Table- 1 summarizes currently available medications for leishmaniasis.

Antimicrobial peptides (AMPs) are short peptides normally isolated from natural sources and these are conserved components of the natural immunity. Therefore they are also known as host defense peptides (HDPs) with a broad range of activity from antimicrobial effects to immunomodulation [18-20]. These are peptides shorter than 50 amino acids in length with cationic net charge and hydrophobic C-terminal [21] and are structurally categorized into five main groups including alpha helical, beta sheet, looped, extended and cyclic structure [22].

In mammals, some of the most rather investigated mHDPs are defensins and cathelicidins [23]. Human defensins are divided into two groups; alpha and beta [24]. Human neutrophil peptide 
(HNP1- 4) and human defensin (HD5 and 6) are alpha defensins with myeloid cell and paneth cell origin, respectively. Beta defensins include human beta defensin (HBD1 to 3) [25-29], which are almost expressed constitutively in epithelial cells, monocytes, macrophages and dendritic cells [30, 31]. However expression could be up-regulated in response to pro-inflammatory cytokines like in HNP-1 case, induced by NF-kB stimulation like in HBD-2 case or induced by bacteria like in HBD-3 and 4 case [31-34]. Mammalian cathelicidins are less frequent with few members identified. LL-37 is the only single cathelicidin identified in human and is produced by different cell types [35-38]. The expression of mHDPs and/or mAMPs can be either constitutive or inducible, depending on the peptide and the cell [39]. Although LL-37 is constitutively expressed in different cells, the expression in epithelial cells is also induced by inflammatory conditions, infection, wounding and vitamin D3 [40-44].

As mentioned above, novel anti-Leishmania drug development is quite indispensable in respect to the disease control. Since HDPs are currently under massive investigation in different infections but are less studied in leishmanisis, here we reviewed different features of these natural molecules including mode of action and immunomodulatory roles during immune response with emphasis on the future of Leishmania treatment using mHDPs.

\section{Anti-leishmanial mHDPs}

Most of the HDPs already known reactive against Leishmania are peptides isolated from livings other than natural hosts of Leishmania such as frog and insects. However, the number of mHDPs able to kill Leishmania species is small compared with that of fungi and bacteria. Table 2 summarizes most of the mHDPs screened against Leishmania promastigotes.

\section{mHDPs mediate direct microbial killing}

In general, most of the AMPs (HDPs) are able to distinguish the plasma membrane in the target organism and cause target cell disruption [52-54]. Three different models (barrel-stave pore, toroidal pore, and membrane thinning and packing disorder) explain the interaction between the HDP and the lipid membrane. In Barrel-Stave model, the peptide is integrated into the membrane

112 bilayer, whereas in toroidal pore model, the peptide binding cause curvature strain resulting in membrane disintegration. In the membrane thinning and packaging disorder model, peptide 
Bera et al. shows that AMPs are less effective on LPG deficient parasites than on wild-type parasites [51].

Several HDPs also traverse microbial plasma membrane instead of disrupting the membrane and reach the Leishmania intracellular targets [55]. Kulkarni et al. showed that cathelicidin-type HDPs including protegrin-1, SMAP-18, 27, and defensins do not induce apoptosis [45], while pexiganan induces caspase 3/7 activity and finally causes apoptotic cell death [56]. Scanning electron microscopy revealed that low concentrations of BMAP-18 can cause apoptotic cell death by disrupting the mitochondrial membrane. However, higher concentrations of BMAP-18 cause necrosis by induction of cell membrane damage [49]. Finally, indolicidin causes cell death by both membrane disruption and induction of autophagy [51]. Fig. 1 schematically illustrates different models of traversing mechanism related to HDPs.

\section{mHDPs as immunomodulators}

mHDPs not only have antimicrobial activity but also they can modulate some biological activities [57,58]. To name they are reported as potent immunomodulators. This function is fulfilled while the peptide interacts with the exterior cell receptors. HDPs then traverse the plasma membrane and bind to the intracellular receptors and induce the signaling pathways. Transcription factors which are important in innate immunity, inhibition of neutrophil apoptotic process, formation of neutrophil extracellular traps (NET), and mast cell derived extracellular traps (MCET), autophagy and maturation of dendritic cells are subsequently activated. Overall these actions promote wound healing and immune hemostasis [59, 60]. Table 3 describes some of the mHDPs and their roles as immunomodulators.

\section{mHDPs mediate transition between pro- and anti-inflammatory responses}

The innate immune system is composed of different cell types and molecules that should obviously work in balance. The HDPs are among effective molecules that have potential influence on this balance during inflammatory responses [86]. Evidently, up-regulated LL-37 expression in epithelial cells (as the source of this molecule) upon encountering with infectious agents result in chemotactic migration of leukocytes, cytokine production and histamine release at the inflammation site [87-89]. Recently Mookherjee et al. have shown that LL-37 induces proinflammatory cytokines including IL-1 $\beta$, IL-6 and IL-8 and also chemokines as MCP-1 and 
MCP-3 besides activation of transcription factors such as Akt, CREB and NF-kB subunits [86]. Neutrophil released HNPs on the other hand, also play an important role to promote TNF- $\beta$ and IFN- $\gamma$ from macrophages which further trigger bacterial phagocytosis via enhancement of CD32 and CD64 expression [75].

It is clear that uncontrolled inflammatory responses are tremendously hazardous to self- tissues and cause Human Inflammatory Diseases (HID). In this respect, apoptosis is a very important inflammation regulator; however in HID, elevated levels of apoptosis due to reactive oxygen stress promotes pathogenesis [64, 90]. So, as previously described, the balance between inflammatory and anti-inflammatory responses actively determines the consequence of the inflammation. Since anti-microbial peptides are multi-functional molecules, they could take the responsibility of inflammation regulation during infection [91-95]. Considering HBD1-4 are key players during infection, they can induce Bcl-x, an anti-apoptotic molecule and also caspase-3. Besides, LL-37 can down-regulate pro- inflammatory response induced by LPS and it can clear inflammatory mediated cells through phagocytosis as well as ROS (reactive oxygen stress) production in inflammatory response $[96,97]$. The study on cutaneous leishmaniasis case has demonstrated uncontrolled parasite growth and profound lesion in CRAMP knockout mouse, is related to cathelicidin family. This study shows the importance of HDPs as modulators in inflammatory response [56].

\section{mHDPs promote wound healing}

Besides the role of mHDPs as antimicrobials and regulators of the immune response, these molecules have also potential role in wound healing. Wound healing has three main phases: inflammation (mononuclear cell extravasation for removing debris), granulation (collagen production and accumulation) and finally re-epithalization phase. Some studies have shown that expression of HDPs is up-regulated in the skin wounds and contributes in wound healing [74]. In vitro studies of HNP-1 showed its mitogenic effect on different cell lines such as fibroblasts and epithelial cells [98]. In another study, HNP-1 stimulated expression of pro-collagen mRNA while down-regulating matrix metalloproteinase (collagen degradation) in dermal fibroblasts [99]. According to Niyonsaba et al., beta defensins can participate in wound healing by regulating the migration and multiplication of epidermal keratinocytes [100]. Kaus et al. observed that mRNA expression of LL-37 and HBD1-3 discriminates between burnt and healthy skins. Despite HBD- 
1741 which is less expressed in burnt wounds, HBD-2 was observed to be up-regulated about 380

175 folds. In contrast the expression of HBD-3's mRNA raises only 10 folds [101]. Wound and burnt 176 damages are usually accompanied with antibiotic resistant microbial infections. Therefore

177 harnessing the ability of these peptides in killing bacteria and modulation of inflammatory

178 responses, could be promising in wound healing after Leishmania infection.

179 mHDPs play a role in innate and adaptive immunity

180 The inflammatory response initiates after recognition of microbial signature by toll like receptors 181 (TLR) [40]. The change in cellular milieu can activate HDPs such as LL-37, in addition to 182 antimicrobial effect directly. This peptide can attract different types of innate immunity cells 183 (monocytes, dendritic cells and neutrophils) to clear infection by enhancing autophagy in 184 185 186 187 macrophages, induction of anti-apoptotic protein expression and neutrophil phagocytosis [102, 103]. However activation of innate immunity alone is not enough to clear infection and requires proper adaptive immune response. LL-37 can activate adaptive immunity via mediating differentiation, maturation and migration of dendritic cells to secondary lymphoid organs to stimulate specific lymphocyte and response [40, 64]. As mentioned before, there are some controversial points about LL-37. Several studies have shown the ability of LL-37 in TLR-4 signal suppression by different mechanisms such as IkB degradation but another study showed an opposite result, TLR activation as well as its signaling suppression [104, 105].

In the same mechanism defensins have antimicrobial effect directly. They can influence both innate and adaptive immune response. Beta defensins can modulate adaptive immunity by both recruiting the immature dendritic cells to the damaged site and activating dendritic cell maturation through TLR-4 [30]. Studies on corneal epithelial cell have revealed that the response to TLR provocation is mostly regulated by defensins and self-regulated TLR mRNA [106-108].

\section{mHDPs as alarmins}

Alarmins (warning molecules) are components of the immune response with certain characteristics. They are classified in four groups: a) HDPs such as defensins and cathelicidins, b) nuclear binding proteins, c) heat shock proteins and d) extracellular matrix of degenerated products [109]. Alarmins are constitutively released in response to infection and have specific receptors. For example defensins bind to CCR2, CCR6 and TLR4 whereas cathelicidins bind to 
FPRL1/2, TLR7 and TLR8. Receptor binding then activates antigen presenting cells and dendritic cells to promote immune response [77, 109]. Alarmins increase differentiation of predendritic cells to immature dendritic cells. In addition, they enhance antigen uptake and processing by immature dendritic cells and promote their maturation and migration to lymph nodes to initiate the immune response. Altogether, alarmin molecules can trigger the activation of $\mathrm{T}$ cells and adaptive immune response by promoting antigen uptake, processing, and presentation by antigen-presenting cells (APCs) [77].

Alarmins can also act as chemotactic factors for different leukocytes. Alpha defensins can be chemotactic for naïve $\mathrm{CD} 4^{+}$and $\mathrm{CD} 8^{+} \mathrm{T}$ cells and immature dendritic cells [62]. HBD-1, 2 and 3 can motivate T cells and immature dendritic cells [110, 11], while HBD-3 and HBD-4 motivate monocytes [34, 63]. Besides, cathelicidines can be chemotactic for $\mathrm{T}$ cells, monocytes and neutrophils [62]. Innate immune response is promoted by defensins and cathelicidins via induction of histamine, prostaglandins and chemokines (e.g. CCL2/MCP-1, CXCL8/IL8, and CXCL2/MIP2) [28, 62, 112, 113]. Remarkably, some chemokines can directly act as an antimicrobial and even leishmaniacidal agents in addition to their function as immunological mediator [114-116]. Figure 2 shows the function of mHDPs as alarmins in wound healing.

\section{Immunobiology and healing or non-healing process in leishmaniasis}

Undoubtedly, clearance of the infection in leishmaniasis depends on the balance between components of the cellular immune response. The balance between Th1 and Th2 response is an essential issue for protection phenotype. In other words, healing of the ulcers in leishmaniasis requires proper cells and cytokines interaction [117]. The major pre-requisite of wound healing in leishmaniasis is the IL-12 induced establishment of Th1 cell response and IFN- $\gamma$ induced activation of macrophages [118-121]. Dendritic cells play an important role in inducing the conversion of naïve $\mathrm{T}$ cells to regulatory $\mathrm{T}$ cells which induces the persistence of the parasite post-infection [122].

On the contrary, progressive pathogenesis have been attributed to skewed Th2 response and involvement of different cytokines secretion including IL-4, IL-5 and IL-13 [123]. Hence, differentiation of naïve $\mathrm{T}$ cells to either Th1 or Th2 cells basically depends on the priming 
231 condition. Schematic illustration of healing and non-healing responses in cutaneous 232 leishmaniasis is shown in Fig 3.

\section{HDPs as therapeutic agents and their concerns}

234 As shown so far, mHDPs potentially modulate the immune response, therefore have been considered promising drug candidates against parasite propagation, either alone or in combination with other antibiotics. However there are a few in vivo studies about the impact of

237 the HDPs on leishmaniasis. Among all, HNP-1 which is produced by neutrophils is one of the most potent defensins. Our in vitro studies showed a promising effect of recombinant HNP-1 as an anti-leishmanial agent on L. major promastigotes and amastigotes [46]. Furthermore, the rate of neutrophil infectivity decreased after HNP-1 treatment. Also the apoptosis was delayed in infected neutrophils. Based on these in vitro results, we have further expanded the idea to examine the therapeutic effect of HNP1 in different approaches in infected mice with L. major.

Although the HDPs are attractive molecules in respect to their effect on immune response as immunomodulators, however toxicity, susceptibility to enzymatic digestion, high production costs, and instability are some drawbacks that have hampered their use. Of course not all the HDPs have these characteristics. One possible solution to resolve the problem is the application of peptidomimetics [124].

Using peptidomimetics (analyzing the relationship between structure and function, then balancing the forces for enhanced function of peptide) can be a suitable way for manipulating HDPs and decreasing their toxicity and synthesis costs [124-127]. As an alternative, synthesis costs of these peptides can be reduced by using prokaryotic systems for recombinant peptides

252 production. InnateDB can be used to predict unwanted interactions with immune system 253 molecules. Furthermore, instability problem can be solved using D-peptides or non-ordinary 254 peptides and special formulations for delivery [20].

\section{Conclusion}

Developing new drugs against Leishmania is an important concern due to increasing resistance to current therapeutic chemicals. Overall, mammalian HDPs with several potential antimicrobial

258 and immunomodulatory effects could be used to elicit and control the immune response. These 
259 potent immunostimulants, are not much studied in the field of leishmaniasis and are potentially

260 valued for further evaluation in respect to Leishmania infection.

\section{Acknowledgment}

262 Zahra Abdossamadi thanks Pasteur Institute of Iran for supporting her Ph.D. studentship. This

263 work was supported by Pasteur Institute of Iran (grant ID 705) and National Science Foundation 264 of Iran (grant number 43723) to SR. We also wish to thank Amir Mizbani (ETH Zurich) for 265 English proofreading of the manuscript and Mahdi Mohammadi (Art university of Tehran) for 266 figures' art design.

267

268

269

270

271

272

273

274

275

276

277

278

279

280

281 


\section{References}

283 [1] W.H. Organization, Control of the leishmaniases, World Health Organization, Tech Rep Ser, (2010) $284 \quad 1-186$.

285 [2] M.C. Boite, I.L. Mauricio, M.A. Miles, E. Cupolillo, New insights on taxonomy, phylogeny and 286 population genetics of Leishmania (Viannia) parasites based on multilocus sequence analysis, PLoS, 6 287 (2012) e1888.

[3] A.M. Musa, S. Noazin, E.A. Khalil, F. Modabber, Immunological stimulation for the treatment of leishmaniasis: a modality worthy of serious consideration, Trans R Soc Trop Med Hyg, 104 (2010) 1-2.

[4] M. Orsini, J.R. Canela, J. Disch, F. Maciel, D. Greco, A. Toledo, Jr., A. Rabello, High frequency of asymptomatic Leishmania spp. infection among HIV-infected patients living in endemic areas for visceral leishmaniasis in Brazil, T Roy Soc Trop Med H, 106 (2012) 283-288.

[5] D. Sacks, C. Anderson, Re-examination of the immunosuppressive mechanisms mediating non-cure of Leishmania infection in mice, Immunol Rev, 201 (2004) 225-238.

[6] S. Besteiro, R.A. Williams, G.H. Coombs, J.C. Mottram, Protein turnover and differentiation in Leishmania, Int J Parasitol, 37 (2007) 1063-1075.

[7] L. Rivas, J.R. Luque-Ortega, D. Andreu, Amphibian antimicrobial peptides and Protozoa: lessons from parasites, BBA-biomembrance, 1788 (2009) 1570-1581.

[8] D. Légaré, M. Ouellette, Drug Resistance in Leishmania, in: M. Gotte, A. A. Berghuis, G. Matasheeski, M. A. Wainberg, D. Sheppard (Eds), Handbook of antimicrobial resistance, Springer, NewYork, (2014) 1-24.

[9] M.A. Lynn, J. Kindrachuk, A.K. Marr, H. Jenssen, N. Pante, M.R. Elliott, S. Napper, R.E. Hancock, W.R. McMaster, Effect of BMAP-28 antimicrobial peptides on Leishmania major promastigote and amastigote growth: role of leishmanolysin in parasite survival, PLoS, 5 (2011) e1141.

[10] S. Mohapatra, Drug resistance in leishmaniasis: Newer developments, Trop Parasitol, 4 (2014) 4-9.

[11] S.L. Croft, K. Seifert, V. Yardley, Current scenario of drug development for leishmaniasis, The Indian J Med Res, 123 (2006) 399-410.

[12] H. Goto, J.A. Lindoso, Current diagnosis and treatment of cutaneous and mucocutaneous leishmaniasis, Expert Rev Anti Infective Ther, 8 (2010) 419-433. 
[13] J.D. Berman, Human leishmaniasis: clinical, diagnostic, and chemotherapeutic developments in the

311 last 10 years, Clin Infect Dis, 24 (1997) 684-703.

312 [14] P.D. Marsden, Personal experience with diagnostic and therapeutic aspects of human Leishmania

313 (Viannia) braziliensis in Tres Bracos, Mem Inst Oswaldo Cruz, 89 (1994) 485-487.

314 [15] K. Seifert, Structures, targets and recent approaches in anti-leishmanial drug discovery and

315 development, Open med Chem J, 5 (2011) 31-39.

316 [16] M. Maarouf, Y. de Kouchkovsky, S. Brown, P.X. Petit, M. Robert-Gero, In vivo interference of

317 paromomycin with mitochondrial activity of Leishmania, Ex Cell Res, 232 (1997) 339-348.

318 [17] J. Lindoso, J. Costa, I. Queiroz, H. Goto, Review of the current treatments for leishmaniases, Res 319 Rep Trop Med, 3 (2012) 69-77.

320 [18] G. Wang, X. Li, Z. Wang, APD2: the updated antimicrobial peptide database and its application in 321 peptide design, Nucleic Acids Res, 37 (2009) D933-937.

322 [19] A. Alba, C. Lopez-Abarrategui, A.J. Otero-Gonzalez, Host defense peptides: an alternative as 323 antiinfective and immunomodulatory therapeutics, Biopolymers, 98 (2012) 251-267.

324 [20] S.C. Mansour, O.M. Pena, R.E. Hancock, Host defense peptides: front-line immunomodulators, 325 Trends Immunol, 35 (2014) 443-450.

326 [21] R.E. Hancock, H.G. Sahl, Antimicrobial and host-defense peptides as new anti-infective therapeutic 327 strategies, Nat Biotechnol, 24 (2006) 1551-1557.

328 [22] R.E. Hancock, Peptide antibiotics, Lancet, 349 (1997) 418-422.

329 [23] P. Dutta, S. Das, Mammalian Antimicrobial Peptides: Promising Therapeutic Targets Against 330 Infection and Chronic Inflammation, Cur Top Med Chem, 16 (2016) 99-129.

331 [24] A.L. Hughes, Evolutionary diversification of the mammalian defensins, Cel Mol Life Sci: CMLS, 56 332 (1999) 94-103.

333 [25] T. Ganz, M.E. Selsted, D. Szklarek, S.S. Harwig, K. Daher, D.F. Bainton, R.I. Lehrer, Defensins. 334 Natural peptide antibiotics of human neutrophils, J Clin Invest, 76 (1985) 1427-1435.

335 [26] D.E. Jones, C.L. Bevins, Paneth cells of the human small intestine express an antimicrobial peptide 336 gene, J Biol Chem, 267 (1992) 23216-23225. 
[27] E.V. Valore, T. Ganz, Posttranslational processing of defensins in immature human myeloid cells, Blood, 79 (1992) 1538-1544.

[28] T. Ganz, Defensins: antimicrobial peptides of innate immunity, Nat Rev Immunol, 3 (2003) 710-720.

[29] T. Ganz, R.I. Lehrer, Antimicrobial peptides of vertebrates, Cur Opin Immunol, 10 (1998) 41-44.

[30] L. Hazlett, M. Wu, Defensins in innate immunity, Cell Tissue Res, 343 (2011) 175-188.

[31] F. Semple, J.R. Dorin, $\alpha$-Defensins: multifunctional modulators of infection, inflammation and more? J Innate Immun, 4 (2012) 337-348.

[32] M. Rodriguez-Garcia, H. Oliva, N. Climent, F. Garcia, J.M. Gatell, T. Gallart, Human immature monocyte-derived dendritic cells produce and secrete alpha-defensins 1-3, J Leukoc Biol, 82 (2007) 1143-1146.

[33] J. Harder, J. Bartels, E. Christophers, J.M. Schroder, Isolation and characterization of human beta defensin-3, a novel human inducible peptide antibiotic, J Biol Chem, 276 (2001) 5707-5713.

[34] J.R. Garcia, A. Krause, S. Schulz, F.J. Rodriguez-Jimenez, E. Kluver, K. Adermann, U. Forssmann, A. Frimpong-Boateng, R. Bals, W.G. Forssmann, Human beta-defensin 4: a novel inducible peptide with a specific salt-sensitive spectrum of antimicrobial activity, FASEB J, 15 (2001) 1819-1821.

[35] E.M. Kosciuczuk, P. Lisowski, J. Jarczak, N. Strzalkowska, A. Jozwik, J. Horbanczuk, J. Krzyzewski, L. Zwierzchowski, E. Bagnicka, Cathelicidins: family of antimicrobial peptides. A review, Mol Biol Rep, 39 (2012) 10957-10970.

[36] G.H. Gudmundsson, K.P. Magnusson, B.P. Chowdhary, M. Johansson, L. Andersson, H.G. Boman, Structure of the gene for porcine peptide antibiotic PR-39, a cathelin gene family member: comparative mapping of the locus for the human peptide antibiotic FALL-39, Proc Natl Acad Sci USA, 92 (1995) 7085-7089.

[37] R. Bals, X. Wang, M. Zasloff, J.M. Wilson, The peptide antibiotic LL-37/hCAP-18 is expressed in epithelia of the human lung where it has broad antimicrobial activity at the airway surface, Proc Natl Acad Sci USA, 95 (1998) 9541-9546.

[38] M. Frohm, B. Agerberth, G. Ahangari, M. Stahle-Backdahl, S. Liden, H. Wigzell, G.H. Gudmundsson, The expression of the gene coding for the antibacterial peptide LL-37 is induced in human keratinocytes during inflammatory disorders, J Bioll Chem, 272 (1997) 15258-15263. 
[39] K.Y. Choi, L.N. Chow, N. Mookherjee, Cationic host defence peptides: multifaceted role in immune modulation and inflammation, J Innate Immun, 4 (2012) 361-370.

[40] D. Vandamme, B. Landuyt, W. Luyten, L. Schoofs, A comprehensive summary of LL-37, the factotum human cathelicidin peptide, Cell Immunol, 280 (2012) 22-35.

[41] A. Nijnik, R.E. Hancock, The roles of cathelicidin LL-37 in immune defences and novel clinical applications, Cur Opin Hematol, 16 (2009) 41-47.

[42] T.T. Wang, F.P. Nestel, V. Bourdeau, Y. Nagai, Q. Wang, J. Liao, L. Tavera-Mendoza, R. Lin, J.W. Hanrahan, S. Mader, J.H. White, Cutting edge: 1,25-dihydroxyvitamin D3 is a direct inducer of antimicrobial peptide gene expression, J Immunol, 173 (2004) 2909-2912.

[43] G. Diamond, N. Beckloff, A. Weinberg, K.O. Kisich, The roles of antimicrobial peptides in innate host defense, Cur Pharm Des, 15 (2009) 2377-2392.

[44] I. Hosokawa, Y. Hosokawa, H. Komatsuzawa, R.B. Goncalves, N. Karimbux, M.H. Napimoga, M. Seki, K. Ouhara, M. Sugai, M.A. Taubman, T. Kawai, Innate immune peptide LL-37 displays distinct expression pattern from beta-defensins in inflamed gingival tissue, Clin Exp Immunol, 146 (2006) 218225.

[45] M.M. Kulkarni, W.R. McMaster, E. Kamysz, W. Kamysz, D.M. Engman, B.S. McGwire, The major surface-metalloprotease of the parasitic protozoan, Leishmania, protects against antimicrobial peptideinduced apoptotic killing, Mol Microbiol, 62 (2006) 1484-1497.

[46] S. Dabirian, Y. Taslimi, F. Zahedifard, E. Gholami, F. Doustdari, M. Motamedirad, S. Khatami, K. Azadmanesh, S. Nylen, S. Rafati, Human neutrophil peptide-1 (HNP-1): a new anti-leishmanial drug candidate, PLoS, 7 (2013) e2491.

[47] M. Torrent, D. Pulido, L. Rivas, D. Andreu, Antimicrobial peptide action on parasites, Cur Drug Targ, 13 (2012) 1138-1147.

[48] J.R. Luque-Ortega, W. van't Hof, E.C. Veerman, J.M. Saugar, L. Rivas, Human antimicrobial peptide histatin 5 is a cell-penetrating peptide targeting mitochondrial ATP synthesis in Leishmania, FASEB J, 22 (2008) 1817-1828. $\alpha$

[49] L.R. Haines, J.M. Thomas, A.M. Jackson, B.A. Eyford, M. Razavi, C.N. Watson, B. Gowen, R.E. Hancock, T.W. Pearson, Killing of trypanosomatid parasites by a modified bovine host defense peptide, BMAP-18, PLoS, 3 (2009) e373. 
[50] F. Tapia, N. Díaz, O. Rodriguez, M. Sánchez, Tegumentary leishmaniasis: immunology and molecular biology, Gaz Méd Bahia, (2009) 84-90.

[51] A. Bera, S. Singh, R. Nagaraj, T. Vaidya, Induction of autophagic cell death in Leishmania donovani by antimicrobial peptides, Mol Bio Parasitol, 127 (2003) 23-35.

[52] S.L. Cobb, P.W. Denny, Antimicrobial peptides for leishmaniasis, Cur Opin Investig Drugs, 11 (2010) 868-875.

[53] M.L. Mangoni, J.M. Saugar, M. Dellisanti, D. Barra, M. Simmaco, L. Rivas, Temporins, small antimicrobial peptides with leishmanicidal activity, Journal Biol Chem, 280 (2005) 984-990.

[54] B.S. McGwire, M.M. Kulkarni, Interactions of antimicrobial peptides with Leishmania and trypanosomes and their functional role in host parasitism, Exp Parasitol, 126 (2010) 397-405.

[55] M. Malmsten, Antimicrobial peptides, Ups J Med Sci, 119 (2014) 199-204.

[56] M.M. Kulkarni, W.R. McMaster, W. Kamysz, B.S. McGwire, Antimicrobial peptide-induced apoptotic death of leishmania results from calcium-de pend ent, caspase-independent mitochondrial toxicity, J Biol Chem, 284 (2009) 15496-15504.

[57] M. Zasloff, Antimicrobial peptides of multicellular organisms, Nature, 415 (2002) 389-395.

[58] R.E. Hancock, E.F. Haney, E.E. Gill, The immunology of host defence peptides: beyond antimicrobial activity, Nat Rev Immunol, 16 (2016) 321-334.

[59] A.L. Hilchie, K. Wuerth, R.E. Hancock, Immune modulation by multifaceted cationic host defense (antimicrobial) peptides, Nat Chem Biol, 9 (2013) 761-768.

[60] M. Hemshekhar, V. Anaparti, N. Mookherjee, Functions of Cationic Host Defense Peptides in Immunity, Pharmaceuticals, 9 (2016) e40.

[61] C. Auvynet, Y. Rosenstein, Multifunctional host defense peptides: antimicrobial peptides, the small yet big players in innate and adaptive immunity, FEBS J, 276 (2009) 6497-6508.

[62] D. Yang, A. Biragyn, D.M. Hoover, J. Lubkowski, J.J. Oppenheim, Multiple roles of antimicrobial defensins, cathelicidins, and eosinophil-derived neurotoxin in host defense, Annu Rev Immunol, 22 (2004) 181-215. 
[63] J.R. Garcia, F. Jaumann, S. Schulz, A. Krause, J. Rodriguez-Jimenez, U. Forssmann, K. Adermann, E. Kluver, C. Vogelmeier, D. Becker, R. Hedrich, W.G. Forssmann, R. Bals, Identification of a novel, multifunctional beta-defensin (human beta-defensin 3) with specific antimicrobial activity. Its interaction with plasma membranes of Xenopus oocytes and the induction of macrophage chemoattraction, Cell Tissue Res, 306 (2001) 257-264.

[64] K.Y. Choi, N. Mookherjee, Multiple immune-modulatory functions of cathelicidin host defense peptides, Front Immunol, 3 (2012) 149.

[65] G.S. Tjabringa, D.K. Ninaber, J.W. Drijfhout, K.F. Rabe, P.S. Hiemstra, Human cathelicidin LL-37 is a chemoattractant for eosinophils and neutrophils that acts via formyl-peptide receptors, Int Arch Allergy Immunol, 140 (2006) 103-112.

[66] M.G. Scott, D.J. Davidson, M.R. Gold, D. Bowdish, R.E. Hancock, The human antimicrobial peptide LL-37 is a multifunctional modulator of innate immune responses, J Immunol, 169 (2002) 3883-3891.

[67] Y. Lai, R.L. Gallo, AMPed up immunity: how antimicrobial peptides have multiple roles in immune defense, Trends Immunol, 30 (2009) 131-141.

[68] Y.E. Lau, A. Rozek, M.G. Scott, D.L. Goosney, D.J. Davidson, R.E. Hancock, Interaction and cellular localization of the human host defense peptide LL-37 with lung epithelial cells, Infect Immun, 73 (2005) 583-591.

[69] N. Mookherjee, R.E. Hancock, Cationic host defence peptides: innate immune regulatory peptides as a novel approach for treating infections, Cell Mol Life Sci : CMLS, 64 (2007) 922-933.

[70] J. Shi, S. Aono, W. Lu, A.J. Ouellette, X. Hu, Y. Ji, L. Wang, S. Lenz, F.W. van Ginkel, M. Liles, C. Dykstra, E.E. Morrison, C.O. Elson, A novel role for defensins in intestinal homeostasis: regulation of IL1beta secretion, J Immunol, 179 (2007) 1245-1253.

[71] K. Miles, D.J. Clarke, W. Lu, Z. Sibinska, P.E. Beaumont, D.J. Davidson, T.A. Barr, D.J. Campopiano, M. Gray, Dying and necrotic neutrophils are anti-inflammatory secondary to the release of alpha-defensins, J Immunol, 183 (2009) 2122-2132.

[72] L.C. Pingel, K.G. Kohlgraf, C.J. Hansen, C.G. Eastman, D.E. Dietrich, K.K. Burnell, R.N. Srikantha, X. Xiao, M. Belanger, A. Progulske-Fox, J.E. Cavanaugh, J.M. Guthmiller, G.K. Johnson, S. Joly, Z.B. Kurago, D.V. Dawson, K.A. Brogden, Human beta-defensin 3 binds to hemagglutinin B (rHagB), a non- 
fimbrial adhesin from Porphyromonas gingivalis, and attenuates a pro-inflammatory cytokine response, Immunol Cell Biol, 86 (2008) 643-649.

[73] F. Niyonsaba, H. Ushio, I. Nagaoka, K. Okumura, H. Ogawa, The human beta-defensins (-1, -2, -3, 4) and cathelicidin LL-37 induce IL-18 secretion through p38 and ERK MAPK activation in primary human keratinocytes, J Immunol, 175 (2005) 1776-1784.

[74] L. Steinstraesser, T. Koehler, F. Jacobsen, A. Daigeler, O. Goertz, S. Langer, M. Kesting, H. Steinau, E. Eriksson, T. Hirsch, Host defense peptides in wound healing, Mol Med, 14 (2008) 528-537.

[75] O. Soehnlein, Y. Kai-Larsen, R. Frithiof, O.E. Sorensen, E. Kenne, K. Scharffetter-Kochanek, E.E. Eriksson, H. Herwald, B. Agerberth, L. Lindbom, Neutrophil primary granule proteins HBP and HNP1-3 boost bacterial phagocytosis by human and murine macrophages, J Clin Invest, 118 (2008) 3491-3502.

[76] E.K. Jo, Innate immunity to mycobacteria: vitamin D and autophagy, Cell Microbiol, 12 (2010) 1026-1035.

[77] J.J. Oppenheim, D. Yang, Alarmins: chemotactic activators of immune responses, Cur Opin Immunol, 17 (2005) 359-365.

[78] M. Rodriguez-Garcia, H. Oliva, N. Climent, M.M. Escribese, F. Garcia, T.M. Moran, J.M. Gatell, T. Gallart, Impact of alpha-defensins1-3 on the maturation and differentiation of human monocyte-derived DCs. Concentration-dependent opposite dual effects, Clin Immunol, 131 (2009) 374-384

[79] D.J. Davidson, A.J. Currie, G.S. Reid, D.M. Bowdish, K.L. MacDonald, R.C. Ma, R.E. Hancock, D.P. Speert, The cationic antimicrobial peptide LL-37 modulates dendritic cell differentiation and dendritic cell-induced T cell polarization, J Immunol, 172 (2004) 1146-1156.

[80] L. Bandholtz, G.J. Ekman, M. Vilhelmsson, E. Buentke, B. Agerberth, A. Scheynius, G.H. Gudmundsson, Antimicrobial peptide LL-37 internalized by immature human dendritic cells alters their phenotype, Scand J immunol, 63 (2006) 410-419.

[81] K.W. Miller, R.J. Evans, S.P. Eisenberg, R.C. Thompson, Secretory leukocyte protease inhibitor binding to mRNA and DNA as a possible cause of toxicity to Escherichia coli, J Bacteriol, 171 (1989) 2166-2172.

[82] M.R. Bleackley, B.M. Hayes, K. Parisi, T. Saiyed, A. Traven, I.D. Potter, N.L. van der Weerden, M.A. Anderson, Bovine pancreatic trypsin inhibitor is a new antifungal peptide that inhibits cellular magnesium uptake, Mol Microbiol, 92 (2014) 1188-1197. 
477 [83] L. Marischen, D. Wesch, J.M. Schroder, O. Wiedow, D. Kabelitz, Human gammadelta T cells

478 produce the protease inhibitor and antimicrobial peptide elafin, Scand J Immunol, 70 (2009) 547-552.

479 [84] K.A. Brogden, M. Heidari, R.E. Sacco, D. Palmquist, J.M. Guthmiller, G.K. Johnson, H.P. Jia, B.F.

480 Tack, P.B. McCray, Defensin-induced adaptive immunity in mice and its potential in preventing

481 periodontal disease, Oral Microbiol Immunol, 18 (2003) 95-99.

482 [85] A.T. Yeung, S.L. Gellatly, R.E. Hancock, Multifunctional cationic host defence peptides and their 483 clinical applications, Cell Mol Life Sci : CMLS, 68 (2011) 2161-2176.

484 [86] J. Yu, N. Mookherjee, K. Wee, D.M. Bowdish, J. Pistolic, Y. Li, L. Rehaume, R.E. Hancock, Host 485 defense peptide LL-37, in synergy with inflammatory mediator IL-1beta, augments immune responses by 486 multiple pathways, J Immunol, 179 (2007) 7684-7691.

487 [87] A.D. Befus, C. Mowat, M. Gilchrist, J. Hu, S. Solomon, A. Bateman, Neutrophil defensins induce 488 histamine secretion from mast cells: mechanisms of action, J Immunol, 163 (1999) 947-953.

489 [88] F. Niyonsaba, K. Iwabuchi, A. Someya, M. Hirata, H. Matsuda, H. Ogawa, I. Nagaoka, A 490 cathelicidin family of human antibacterial peptide LL-37 induces mast cell chemotaxis, Immunology, 106 491 (2002) 20-26.

492 [89] F. Niyonsaba, A. Someya, M. Hirata, H. Ogawa, I. Nagaoka, Evaluation of the effects of peptide 493 antibiotics human beta-defensins-1/-2 and LL-37 on histamine release and prostaglandin $\mathrm{D}(2)$ production 494 from mast cells, Eur J Immunol, 31 (2001) 1066-1075.

495 [90] S. Nowsheen, E.S. Yang, The intersection between DNA damage response and cell death pathways, 496 Exp Oncol, 34 (2012) 243-254.

497 [91] T. Schuerholz, K. Brandenburg, G. Marx, Antimicrobial peptides and their potential application in 498 inflammation and sepsis, Crit Care, 16 (2012) 207.

499 [92] B. Ramanathan, H. Wu, C.R. Ross, F. Blecha, PR-39, a porcine antimicrobial peptide, inhibits 500 apoptosis: involvement of caspase-3, Dev Comp Immunol, 28 (2004) 163-169.

501 [93] M. Pushpanathan, P. Gunasekaran, J. Rajendhran, Antimicrobial peptides: versatile biological 502 properties, Int J Pept, 2013 (2013) 675391. 
[94] F. Guilhelmelli, N. Vilela, P. Albuquerque, S. Derengowski Lda, I. Silva-Pereira, C.M. Kyaw, Antibiotic development challenges: the various mechanisms of action of antimicrobial peptides and of bacterial resistance, Front Microbiol, 4 (2013) 353.

[95] J. Cho, I.S. Hwang, H. Choi, J.H. Hwang, J.S. Hwang, D.G. Lee, The novel biological action of antimicrobial peptides via apoptosis induction, J Microbiol Biotechnol, 22 (2012) 1457-1466.

[96] I. Nagaoka, F. Niyonsaba, Y. Tsutsumi-Ishii, H. Tamura, M. Hirata, Evaluation of the effect of human beta-defensins on neutrophil apoptosis, Int Immunol, 20 (2008) 543-553.

[97] K.L. Brown, G.F. Poon, D. Birkenhead, O.M. Pena, R. Falsafi, C. Dahlgren, A. Karlsson, J. Bylund, R.E. Hancock, P. Johnson, Host defense peptide LL-37 selectively reduces proinflammatory macrophage responses, J Immunol, 186 (2011) 5497-5505.

[98] C.J. Murphy, B.A. Foster, M.J. Mannis, M.E. Selsted, T.W. Reid, Defensins are mitogenic for epithelial cells and fibroblasts, J Cell Physiol, 155 (1993) 408-413.

[99] T. Oono, Y. Shirafuji, W.K. Huh, H. Akiyama, K. Iwatsuki, Effects of human neutrophil peptide-1 on the expression of interstitial collagenase and type I collagen in human dermal fibroblasts, Arch Dermatol Res, 294 (2002) 185-189.

[100] F. Niyonsaba, H. Ushio, N. Nakano, W. Ng, K. Sayama, K. Hashimoto, I. Nagaoka, K. Okumura, H. Ogawa, Antimicrobial peptides human beta-defensins stimulate epidermal keratinocyte migration, proliferation and production of proinflammatory cytokines and chemokines, Journal Invest Dermatol, 127 (2007) 594-604.

[101] A. Kaus, F. Jacobsen, M. Sorkin, A. Rittig, B. Voss, A. Daigeler, H. Sudhoff, H.U. Steinau, L. Steinstraesser, Host defence peptides in human burns, Burns, 34 (2008) 32-40.

[102] J.M. Yuk, D.M. Shin, H.M. Lee, C.S. Yang, H.S. Jin, K.K. Kim, Z.W. Lee, S.H. Lee, J.M. Kim, E.K. Jo, Vitamin D3 induces autophagy in human monocytes/macrophages via cathelicidin, Cell Host Microbe, 6 (2009) 231-243

[103] I. Nagaoka, H. Tamura, M. Hirata, An antimicrobial cathelicidin peptide, human CAP18/LL-37, suppresses neutrophil apoptosis via the activation of formyl-peptide receptor-like 1 and P2X7, J Immunol, 176 (2006) 3044-3052.

[104] N. Mookherjee, K.L. Brown, D.M. Bowdish, S. Doria, R. Falsafi, K. Hokamp, F.M. Roche, R. Mu, G.H. Doho, J. Pistolic, J.P. Powers, J. Bryan, F.S. Brinkman, R.E. Hancock, Modulation of the TLR- 
532 mediated inflammatory response by the endogenous human host defense peptide LL-37, J Immunol, 176 533 (2006) 2455-2464.

534 [105] A. Di Nardo, M.H. Braff, K.R. Taylor, C. Na, R.D. Granstein, J.E. McInturff, S. Krutzik, R.L. 535 Modlin, R.L. Gallo, Cathelicidin antimicrobial peptides block dendritic cell TLR4 activation and allergic 536 contact sensitization, J Immunol, 178 (2007) 1829-1834.

537 [106] R.L. Redfern, R.Y. Reins, A.M. McDermott, Toll-like receptor activation modulates antimicrobial 538 peptide expression by ocular surface cells, Exp Eye Res, 92 (2011) 209-220.

539 [107] P. Ma, Z. Wang, S.C. Pflugfelder, D.Q. Li, Toll-like receptors mediate induction of peptidoglycan 540 recognition proteins in human corneal epithelial cells, Exp Eye Res, 90 (2010) 130-136.

541 [108] D.J. Evans, S.M. Fleiszig, Why does the healthy cornea resist Pseudomonas aeruginosa infection?, 542 Am J Ophthalmol, 155 (2013) 961-970 e962.

543 [109] Y. Nie, D. Yang, J.J. Oppenheim, Alarmins and Antitumor Immunity, Clin Ther, 38 (2016) 1042$544 \quad 1053$.

545 [110] D. Yang, O. Chertov, S.N. Bykovskaia, Q. Chen, M.J. Buffo, J. Shogan, M. Anderson, J.M. 546 Schroder, J.M. Wang, O.M. Howard, J.J. Oppenheim, Beta-defensins: linking innate and adaptive 547 immunity through dendritic and T cell CCR6, Science, 286 (1999) 525-528.

548 [111] A. Biragyn, M. Surenhu, D. Yang, P.A. Ruffini, B.A. Haines, E. Klyushnenkova, J.J. Oppenheim, 549 L.W. Kwak, Mediators of innate immunity that target immature, but not mature, dendritic cells induce 550 antitumor immunity when genetically fused with nonimmunogenic tumor antigens, J Immunol, 167 551 (2001) 6644-6653.

552 [112] M. Zanetti, Cathelicidins, multifunctional peptides of the innate immunity, J leukoc Biol, 75 (2004) $553 \quad 39-48$.

554 [113] U. Andersson, H. Erlandsson-Harris, H. Yang, K.J. Tracey, HMGB1 as a DNA-binding cytokine, J 555 leukoc Biol, 72 (2002) 1084-1091.

556 [114] S.C. Yung, P.M. Murphy, Antimicrobial chemokines, Front Immunol, 3 (2012) 276.

557 [115] G. Wang, Human antimicrobial peptides and proteins, Pharmaceuticals, 7 (2014) 545-594. 
559 antimicrobial peptides with direct parasiticidal effect on Leishmania mexicana in vitro, PloS one, 8 (2013)

560 e58129.

561 [117] U. Sharma, S. Singh, Immunobiology of leishmaniasis, Indian J Exp Biol, 47 (2009) 412-423.

562 [118] A. Awasthi, R.K. Mathur, B. Saha, Immune response to Leishmania infection, Indian J Med Res, $563119(2004) 238-258$.

564 [119] P.M. Gorak, C.R. Engwerda, P.M. Kaye, Dendritic cells, but not macrophages, produce IL-12 565 immediately following Leishmania donovani infection, Eur J Immunol, 28 (1998) 687-695.

566 [120] P. Konecny, A.J. Stagg, H. Jebbari, N. English, R.N. Davidson, S.C. Knight, Murine dendritic cells 567 internalize Leishmania major promastigotes, produce IL-12 p40 and stimulate primary T cell proliferation 568 in vitro, Eur J Immunol, 29 (1999) 1803-1811.

569 [121] M.A. Marovich, M.A. McDowell, E.K. Thomas, T.B. Nutman, IL-12p70 production by Leishmania 570 major-harboring human dendritic cells is a CD40/CD40 ligand-dependent process, J Immunol, 164 (2000) $5715858-5865$.

572 [122] L. Adalid-Peralta, G. Fragoso, A. Fleury, E. Sciutto, Mechanisms underlying the induction of 573 regulatory $\mathrm{T}$ cells and its relevance in the adaptive immune response in parasitic infections, Int $\mathrm{J}$ Biol Sci, 5747 (2011) 1412-1426.

575 [123] M. Gicheru, J. Mutiso, J. Macharia, H. Ozwara, Immunology of leishmaniasis, Sci Parasitol, 14 576 (2013) 51-61.

577 [124] P. Mendez-Samperio, Peptidomimetics as a new generation of antimicrobial agents: current 578 progress, Infec Drug Resist, 7 (2014) 229-237.

579 [125] A. Dragulescu-Andrasi, S. Rapireddy, B.M. Frezza, C. Gayathri, R.R. Gil, D.H. Ly, A simple 580 gamma-backbone modification preorganizes peptide nucleic acid into a helical structure, J Am Chem Soc, $581 \quad 128$ (2006) 10258-10267.

582 [126] T. Tedeschi, S. Sforza, A. Dossena, R. Corradini, R. Marchelli, Lysine-based peptide nucleic acids 583 with strong chiral constraint: control of helix handedness and DNA binding by chirality, PNAs, 17 (2005) 584 196-204. 
585 [127] E. Inokuchi, A. Yamada, K. Hozumi, K. Tomita, S. Oishi, H. Ohno, M. Nomizu, N. Fujii, Design

586 and synthesis of amidine-type peptide bond isosteres: application of nitrile oxide derivatives as active

587 ester equivalents in peptide and peptidomimetics synthesis, Org Biomol Chem, 9 (2011) 3421-3427.

588

589

590

591

592

593

594

595

596

597

598

599

600

601

602

603

604

605

606 


\section{Figure legend}

608 Fig 1. Different action mechanisms of mHDP against Leishmania. (A) Necrosis. Generation of 609 lesions by BMAP-18 and induction of necrosis. (B) Apoptotic cell death by induction of caspase 610 by pexiganan. (C) Induction of autophagy by indolicidin.

611 Fig 2. mHDPs as alarmins and their role in chemotaxis and wound healing.

612 Fig 3. Healing and non-healing responses in cutaneous leishmaniasis

613

614

615

616

617

618

619 


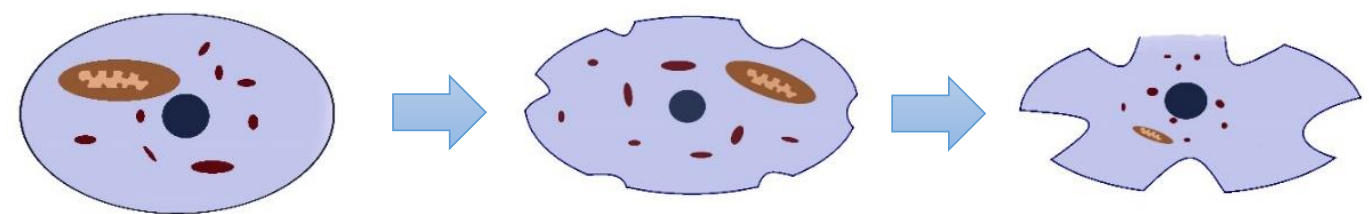

A

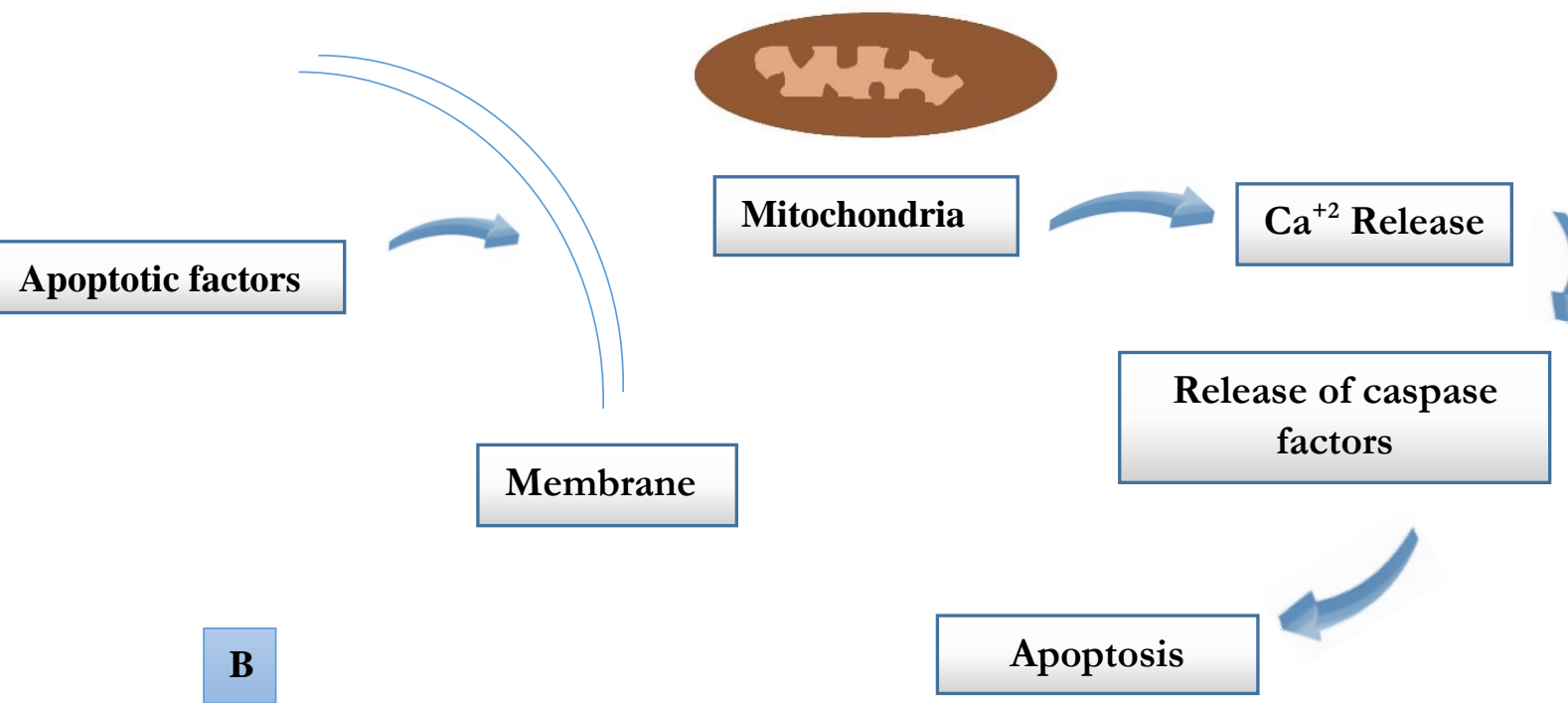

\section{Phagosome}

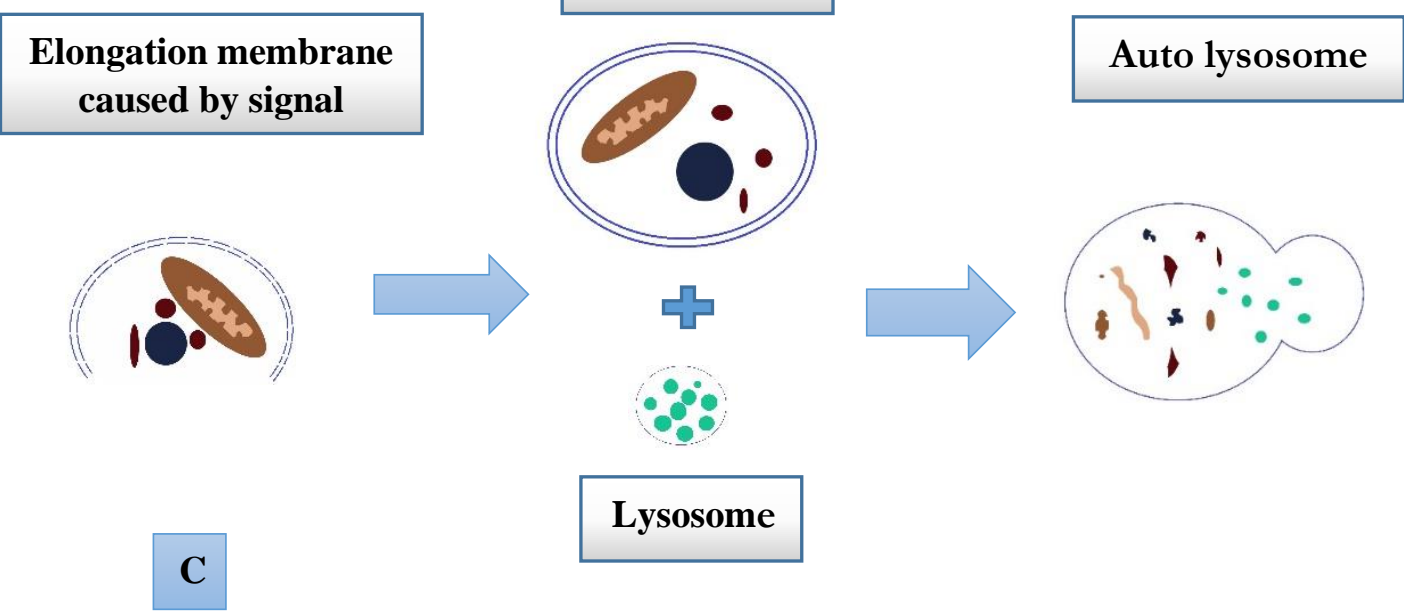

Fig1: Different mechanism of action of mHDPs against Leishmania.

(A) Necrosis. Generation of lesions by BMAP-18 and induction of necrosis. (B) Apoptotic cell death by induction of caspase by pexiganan. (C) Induction of autophagy by indolicidin 


\section{Injury or infection}

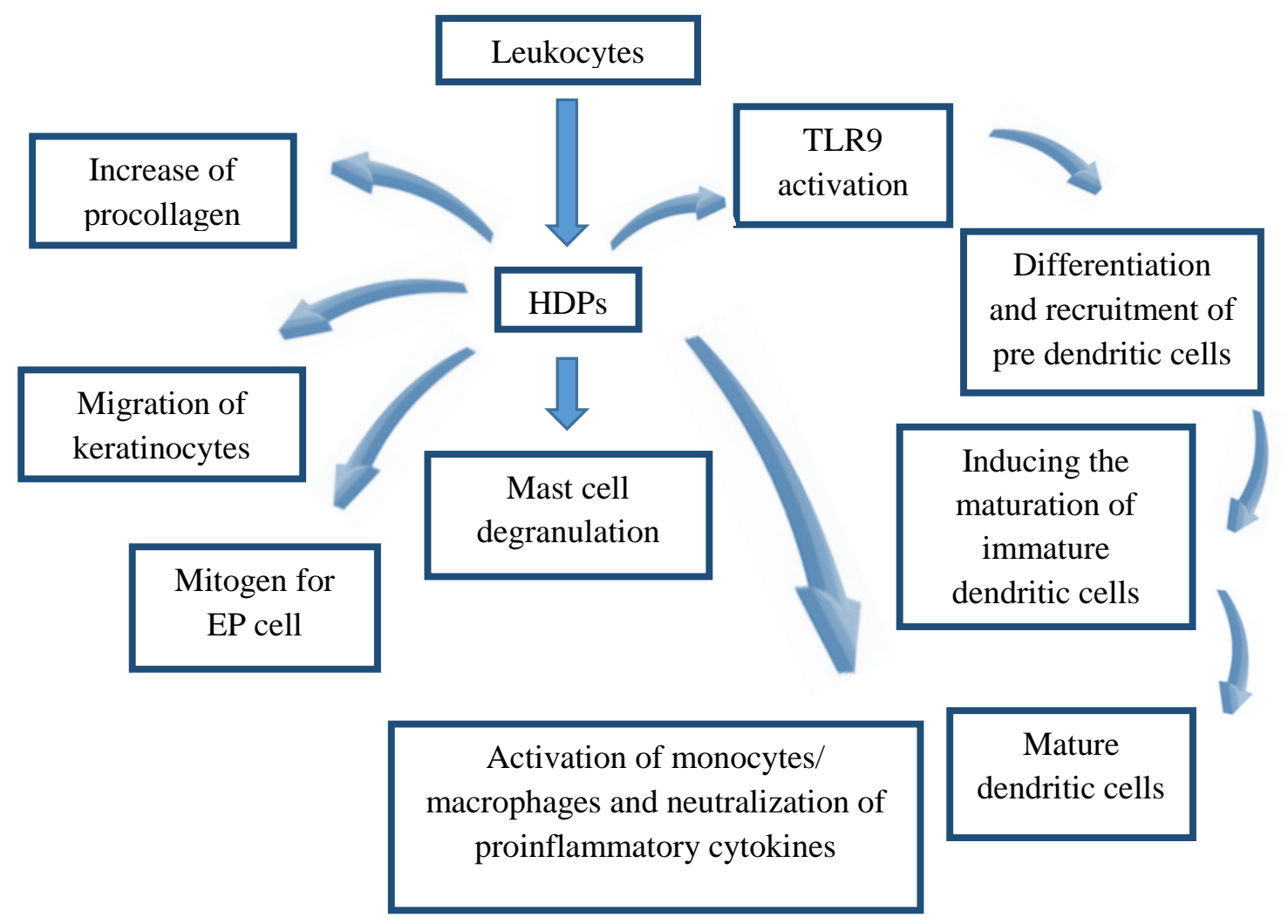

Fig 2. mHDPs as alarmins and their role in chemotaxis and wound healing. 


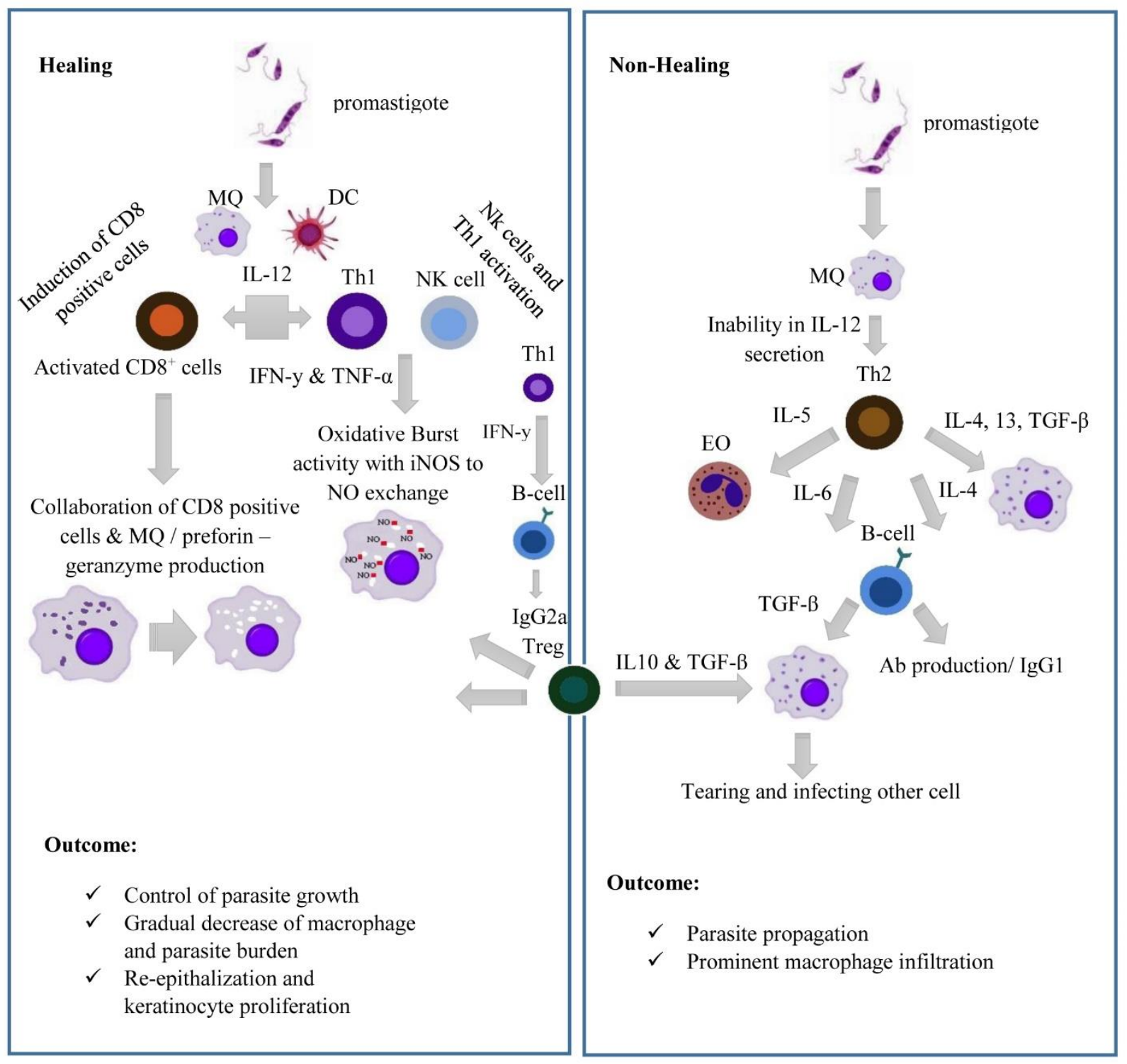

Figure 3. Healing and non-healing responses in cutaneous leishmaniasis. 
Table1. Available treatment regimens for leishmaniasis

\begin{tabular}{|c|c|c|c|c|c|}
\hline Therapeutics & Mode of action & syndrome & administration & Comment/toxicity & Ref \\
\hline $\begin{array}{l}\text { Pentavalent } \\
\text { antimony }\end{array}$ & $\begin{array}{l}\text { Inhibiting the activity of } \\
\text { oxidative and glycolytic } \\
\text { pathways from fatty acids in } \\
\text { amastigotes }\end{array}$ & $\begin{array}{l}\text { CL, VL, } \\
\text { MCL \& } \\
\text { PKDL }^{1}\end{array}$ & $\begin{array}{c}\mathrm{IL}^{2} \text { injection at } \\
20 \mathrm{mg} / \mathrm{Kg} / \text { day for } 20 \text { days or } \\
\text { up to healing } \\
\mathrm{IV}^{3} \text { or } \mathrm{IM}^{4} \text { at } 20 \mathrm{mg} / \mathrm{Kg} / \text { day } \\
\text { for } 28-30 \text { days } \\
\mathrm{IM} 20 \mathrm{mg} / \mathrm{Kg} / \text { day for } 4-5 \\
\text { month }\end{array}$ & $\begin{array}{l}\text { Arthralgia, headache, vomiting, } \\
\text { dizziness, toxic for kidney, heart and } \\
\text { liver. Limited use for pregnant women. } \\
\text { Mortality is high in HIV - Leishmania } \\
\text { co-infected patients (up to 20\%) during } \\
\text { treatment }\end{array}$ & {$[8,11,12]$} \\
\hline Amphotericin B & $\begin{array}{l}\text { To target cell membrane } \\
\text { ergosterol of amastigotes and } \\
\text { promastigotes and increasing } \\
\text { ions influx }\end{array}$ & $\begin{array}{l}\text { CL, VL, } \\
\text { MCL \& } \\
\text { PKDL }\end{array}$ & $\begin{array}{l}\text { IV } 1-5 \mathrm{mg} / \mathrm{kg} / \text { day, alternate } \\
\text { day for 3-4 weeks }\end{array}$ & $\begin{array}{l}\text { several secondary effects such as renal } \\
\text { disturbances, anemia, fever, malaise, } \\
\text { fever, vomiting, hypokalemia and heart } \\
\text { problems }\end{array}$ & {$[8,12-15]$} \\
\hline Miltefosine & $\begin{array}{c}\text { Repressing from sterol and } \\
\text { phospholipid synthesis in } \\
\text { Leishmania }\end{array}$ & VL \& CL & $\begin{array}{c}\text { Oral } \\
100-150 \mathrm{mg} \text { daily for } 28 \\
\text { days }\end{array}$ & $\begin{array}{l}\text { Toxic for renal and gastrointestinal } \\
\text { systems. This molecule is teratogen }\end{array}$ & {$[8,12]$} \\
\hline Paromomycin & $\begin{array}{l}\text { Reduction of membrane } \\
\text { fluidity and interference with } \\
\text { Leishmania mitochondrial } \\
\text { membrane and inhibition of } \\
\text { respiratory process }\end{array}$ & VL \& CL & $\begin{array}{l}\text { IV or IM, } 11-15 \mathrm{mg} / \mathrm{kg} \text { daily } \\
\text { for } 21 \text { days }\end{array}$ & $\begin{array}{l}\text { Toxic effect on the ear. Its sensitive is } \\
\text { much lower for } L \text {. donovani species }\end{array}$ & {$[8,16]$} \\
\hline
\end{tabular}




\begin{tabular}{|c|c|c|c|c|c|}
\hline Pentamidine & $\begin{array}{l}\text { Interference with Leishmania } \\
\text { DNA synthesis }\end{array}$ & $\begin{array}{l}\text { CL, VL, } \\
\text { MCL \& } \\
\text { PKDL }\end{array}$ & $\begin{array}{l}\text { IV or IM, } 2-4 \mathrm{mg} / \mathrm{kg} \text { daily } \\
\text { for } 15 \text { days }\end{array}$ & $\begin{array}{l}\text { Myalgia, hypotension, hypoglycemia and } \\
\text { diabetes mellitus }\end{array}$ & $\begin{array}{c}{[8,11,12,} \\
15]\end{array}$ \\
\hline Fluconazole & $\begin{array}{l}\text { The same as its antifungal } \\
\text { mechanisms }\end{array}$ & CL & $\begin{array}{c}\text { Oral } \\
200 \mathrm{mg} \text { daily for } 6 \text { weeks }\end{array}$ & $\begin{array}{l}\text { Not examined for most species of } \\
\text { Leishmania }\end{array}$ & {$[8,17]$} \\
\hline Ketoconazole & $\begin{array}{l}\text { The same as its antifungal } \\
\text { mechanisms }\end{array}$ & CL & $\begin{array}{c}\text { Oral } \\
600 \mathrm{mg} / \text { day for } 28 \text { days }\end{array}$ & $\begin{array}{c}\text { Cannot be used for L. tropica, and } \\
\text { L. braziliensis }\end{array}$ & {$[8,17]$} \\
\hline
\end{tabular}

${ }^{1}$ Post-kala-azar dermal leishmaniasis (PKDL)

${ }^{2}$ Intralesion (IL)

${ }^{3}$ Intravenous (IV)

${ }^{4}$ Intramuscular (IM) 
Table 2. Activity of mHDPs against Leishmania Spp.

\begin{tabular}{|c|c|c|c|c|c|}
\hline Name & Origin & Leishmania spp. & Parasite type & $\begin{array}{c}\text { Tested } \\
\text { environment }\end{array}$ & Ref \\
\hline$\beta$-defencin I/II/IV & Human Epithelial cell & $\begin{array}{c}\text { L. major, } \\
\text { L. amazonensis* }\end{array}$ & $\begin{array}{l}\text { Promastigote } \\
\text { Amastigote }\end{array}$ & In vitro & {$[45]$} \\
\hline$\theta$-defencin-II & $\begin{array}{c}\text { non-human } \\
\text { (old-world primates) }\end{array}$ & $\begin{array}{c}\text { L. major, } \\
\text { L. amazonensis* }\end{array}$ & Promastigote & In vitro & {$[45]$} \\
\hline HNP-1 & Neutrophils & L. major & $\begin{array}{l}\text { Promastigote } \\
\text { Amastigote }\end{array}$ & In vitro & {$[46]$} \\
\hline AMP-18 & Human myeloid cells & L. major & $\begin{array}{l}\text { Promastigote } \\
\text { Amastigote }\end{array}$ & In vitro & {$[47]$} \\
\hline AMP-28 & Human myeloid cells & L. major & $\begin{array}{l}\text { Promastigote } \\
\text { Amastigote }\end{array}$ & In vitro & {$[47]$} \\
\hline Histatin-5 & Human salivary glands & L. donovani & $\begin{array}{l}\text { Promastigote } \\
\text { Amastigote }\end{array}$ & In vitro & [48] \\
\hline BMAP-18 & $\begin{array}{l}\text { A truncated peptide of } \\
\text { BMAP-27** }\end{array}$ & L. donovani & Promastigote & In vitro & [49] \\
\hline BMAP-28 & Bovine myeloid cells & L. major & $\begin{array}{l}\text { Promastigote } \\
\text { Amastigote }\end{array}$ & In vitro & [9] \\
\hline Protegrin-1 & porcine leukocytes & L. major mutants & Promastigote & In vitro & {$[45]$} \\
\hline LL-37 & Epithelial tissue & L. mexicana & $\begin{array}{l}\text { Promastigote } \\
\text { Amastigote }\end{array}$ & In vitro & {$[50]$} \\
\hline Cryptdin- I & murine Paneth cell & $\begin{array}{c}\text { L. major, } \\
\text { L. amazonensis* }\end{array}$ & Promastigote & In vitro & {$[45]$} \\
\hline
\end{tabular}




\begin{tabular}{|c|c|c|c|c|c|}
\hline Crypdin- IV & murine Paneth cell & $\begin{array}{c}\text { L. major, } \\
\text { L. amazonensis* }\end{array}$ & Promastigote & In vitro & [45] \\
\hline Cathelicidin & $\begin{array}{c}\text { Macrophages, PMNs, } \\
\text { and keratinocytes }\end{array}$ & $\begin{array}{c}\text { L. major, } \\
\text { L. amazonensis* }\end{array}$ & Promastigote & In vitro & [45] \\
\hline Indolicidin & Seminal plasmin & L. donovani & Promastigote & In vitro & [51] \\
\hline SPEK & Seminal plasmin & L. donovani & Promastigote & In vitro & [51] \\
\hline 27PR & Seminal plasmin & L. donovani & Promastigote & In vitro & [51] \\
\hline
\end{tabular}

*L. amazonensis (wild type and leishmanolysin deficient variants)

** By removing nine amino acids from the BMAP-27 C-terminal 
Table3. Immunomodulation of mHDPs in immune response

\begin{tabular}{|c|c|c|}
\hline Collection of biological function & mHDPs & Ref \\
\hline Chemotaxi & HBD-1,HBD-3, HNP1-3, LL-37 & {$[34,61-63]$} \\
\hline $\begin{array}{c}\text { Excitation of } \\
\text { chemokine release }\end{array}$ & LL-37, HBD-2,3 & {$[58,64-66]$} \\
\hline Induction of chemokine receptor & HPD 2-4, LL-37 & [67-69] \\
\hline Induction of cytokine release & HNP1-4, LL-37 & [58] \\
\hline Inflammatory response & LL-37 & {$[66,67]$} \\
\hline $\begin{array}{c}\text { Suppression of the inflammatory } \\
\text { response }\end{array}$ & $\begin{array}{l}\text { LL-37, HNP1-3, } \\
\text { HBD- } 3\end{array}$ & $[70-72]]$ \\
\hline modulation of apoptosis & LL-37, HNP1-4 & {$[58]$} \\
\hline Platelet activation & HNP1-4 & {$[58]$} \\
\hline adjustment of angiogenesis & HBD1-4 & {$[58]$} \\
\hline Wound healing & LL-37, HBD2,3 & {$[73,74]$} \\
\hline Increase of phagocytosis & HNP1-3 & {$[75]$} \\
\hline Promotion of autophagy & HBD1-4 & [76] \\
\hline $\begin{array}{l}\text { Differentiation and maturation } \\
\text { of dendritic cell }\end{array}$ & HNP1-3, LL-37 & [77-80] \\
\hline Anti-protease activity & SLPI*, BPTI**, Elafin & [81-83] \\
\hline Adjuvanticity & defensins & [84] \\
\hline inhibition of complement activation & BMAP-28,indolicidin & [85] \\
\hline
\end{tabular}

* SLPI: Secretory leukocyte protease inhibitor

** BPTI: Bovine pancreatic trypsin inhibitor 